\title{
Correction to: Regression-based mediation analysis: a formula for the bias due to an unobserved precursor variable
}

\author{
Steven B. Kim ${ }^{1}$ • Joonghak Lee ${ }^{2}$
}

Published online: 25 August 2021

(c) Korean Statistical Society 2021

\section{Correction to: Journal of the Korean Statistical Society https://doi.org/10.1007/s42952-021-00105-9}

The article "Regression-based mediation analysis: a formula for the bias due to an unobserved precursor variable", written by Steven B. Kim, et al., was originally published electronically on the publisher's internet portal on 30 January 2021 without open access. With the author' decision to opt for Open Choice the copyright of the article changed on 11 August 2021 to (C) Author(s) 2021 and the article is forthwith distributed under a Creative Commons Attribution 4.0 International License, which permits use, sharing, adaptation, distribution and reproduction in any medium or format, as long as you give appropriate credit to the original author(s) and the source, provide a link to the Creative Commons licence, and indicate if changes were made. The images or other third party material in this article are included in the article's Creative Commons licence, unless indicated otherwise in a credit line to the material. If material is not included in the article's Creative Commons licence and your intended use is not permitted by statutory regulation or exceeds the permitted use, you will need to obtain permission directly from the copyright holder. To view a copy of this licence, visit http://creativecommons.org/licenses/by/4.0.

The original article has been corrected.

The original article can be found online at https://doi.org/10.1007/s42952-021-00105-9.

Joonghak Lee

joonghak.lee@pgr.reading.ac.uk

Steven B. Kim

stkim@csumb.edu

1 Department of Mathematics and Statistics, California State University, Monterey Bay, 100 Campus Center, Seaside, CA 93955, USA

2 International Business and Strategy, Henley Business School, University of Reading, Whiteknights, Reading RG6 6UD, UK 
Publisher's Note Springer Nature remains neutral with regard to jurisdictional claims in published maps and institutional affiliations. 